\title{
Topical tropicamide induced delirium and psychosis: case report
}

\author{
Delírio e psicose induzidos por tropicamida tópica: relato de caso \\ Renato P. Munhoz', Mariana M. Moscovich', Luciane Filla', Maria Cecília Beltrame Carneiro²
}

\section{Keywords}

Tropicamide, psychosis,

cycloplegic, anticholinergic.

\begin{abstract}
Acute psychosis and confusional states are known complications of treatment with anticholinergic agents in the elderly. We report an 87-year-old female patient presenting with acute neurobehavioral abnormalities requiring hospitalization immediately after starting treatment for openangle glaucoma with the topic cycloplegic muscarinic receptor blocker tropicamide. Case-effect relationship was confirmed. The authors make a review of the literature trying to identify the clinical manifestations and risk factors for this complication.
\end{abstract}

\section{RESUMO}

Tratamento com drogas anticolinérgicas é uma causa conhecida de alterações agudas do estado mental em idosos. Relata-se o caso de uma paciente de 87 anos de idade com alterações comportamentais agudas, que necessita de internamento imediatamente após início de terapia para glaucoma de ângulo aberto com tropicamida, um agente cicloplégico bloqueador de receptor muscarínico. A relação causa-efeito foi confirmada depois de a droga ter sido reiniciada durante o internamento. É apresentada uma revisão da literatura delineando as manifestações clínicas mais comuns e fatores de risco para essa complicação.

\section{Palavras-chave \\ Tropicamida, psicose, cicloplégico, anticolinérgico.}

\section{INTRODUCTION}

Acute psychosis and confusional states are known complications of treatment with anticholinergic agents (AChA) in the elderly'. Such adverse effects have also rarely been reported after use of topical cycloplegic muscarinic receptor blockers, including atropine, scopolamine and cyclopentolate ${ }^{2}$. The main pharmacokinetic differences between each of these drugs are time for onset and recovery of cycloplegia ${ }^{3}$.
Although atropine is still widely used, the delay to onset of cycloplegia, the long time required for functional recovery, and the potential for serious side effects have led to use of shorter acting agents ${ }^{3,4}$. Tropicamide is used and marketed as a shorter acting topical ophthalmic AChA used routinely worldwide for diagnostic and therapeutic purposes ${ }^{3}$.

We report a case of an 87 years-old female with acute delirium, psychosis and confusion, leading to hospitalization after use of tropicamide for the treatment of glaucoma deterioration.

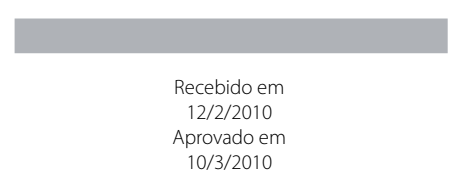

1 Pontifícia Universidade Católica do Paraná (PUC-PR), Hospital Universitário Cajuru, Serviço de Neurologia. 2 Pontifícia Universidade Católica do Paraná (PUC-PR), Hospital Nossa Senhora da Luz, Serviço de Psiquiatria.

Endereço para correspondência: Renato P. Munhoz Trav. Lange, 225 - 80240-170 - Curitiba, PR Telefone: (41) 3244-4483 - Fax: (41) 3244-4483

E-mail: renatopuppi@yahoo.com 


\section{CASE REPORT}

The patient is an 87-year-old woman with a 5 years history of open-angle aphakic glaucoma treated with topical travoprost $0.004 \%$ plus timolol $0.5 \%$. One month before admission she was submitted to right eye cataract (extracapsular) surgery, complicated by severe local pseudomonas aeruginosa infection. Treatment included topical prednisone, ceftazidime, and gatifloxacin. As this approach proved to be ineffective, the patient was eventually submitted to a keratoplasty, leaving additional visual deficits and subsequent decompensation of her glaucoma with a post-dilation intraocular pressure of $25 \mathrm{mmHg}$.

The patient was then started on topical tropicamide 1\% 2 drops, equivalent to $1 \mathrm{mg}$, qid. From the first dose she started with abnormal mental and behavioral status with lowered level of consciousness, acute psychomotor agitation, disorientation and confusion. During these episodes she spoke out loud, presented coherent but illogical thinking, wondered around her house looking for relatives that were deceased or lived away, with abnormal flow of speech, impaired judgment and lack of insight. She also referred vivid and complex visual and kinesthetic hallucinations described as sensations of falling or been pushed from above. The content of her hallucinations included visual perception of familiar relatives and unknown children trying to communicate, with no auditory or tactile perception. These symptoms persisted throughout the day and night but fluctuated in intensity, peaking when tropicamide drops were applied.

After two consecutive days she became more agitated, was unable to be restrained by her care givers and was admitted to our hospital's emergency room. General and neurologic examinations did not reveal additional abnormalities, except for the neuropsychiatric abnormalities described above. Mini mental status examination was not applicable because of her visual deficit. Ophthalmologic examination was not possible in view of the lack of collaboration and agitation. Routine urine and blood tests for metabolic and inflammatory abnormalities were normal. Chest x-ray was unremarkable. Cranial CT and MRI showed moderate diffuse atrophy and periventricular white matter changes compatible with microangiopathy.

Tropicamide was stopped and the patient showed dramatic improvement overnight, returning to her baseline status. The diagnosis of cycloplegic induced psychosis was confirmed in the following day after one of her care givers inadvertently applied the eye drops again, bringing similar neuropsychiatric symptoms that lasted for about six hours. Upon directed questioning, her son and daughter referred that during the previous year she was experiencing subtle but progressive cognitive decline regarding short term memory and executive functioning. These symptoms were not formally assessed by a specialist but were severe enough to leave her partially dependent for part of daily living activities.

The patient was discharged on the third day after admission and referred for a new ophthalmologic assessment.

\section{DISCUSSION}

The precise epidemiologic profile of the occurrence of cognitive and/or behavior changes in outpatients treated with oral AChA remains unknown, especially due to inherent biases and confounding factors in each population studied, including treatment regimens, age group, underlying pathology and so on'. However, advanced age, lower MMSE scores, bereavement and loneliness are generally accepted potential risk factors for such events in the elderly ${ }^{1,5}$. Additionally, visual hallucinations associated with visual deficits (Charles Bonnet syndrome) have been described, especially in the elderly and those with any degree of cognitive abnormalities ${ }^{5,6}$.

The role of cycloplegics as causative agents in acute confusional states and psychosis was first mentioned in the literature in 1935 by Melivier ${ }^{7}$ in a 74 year-old male patient using atropine. Our review of the literature showed that since then, 28 additional reports have been published, mostly as single cases, including 38 individual cases involving five different agents ${ }^{2}$. Two of these cases were using two different cycloplegic agents simultaneously². Demographic and frequency data are shown in table 1. The table also shows that cases occur with no gender predominance and with a wide age range (4 to 75 years old). Atropine, cyclopentolate and scopolamine account for more than $80 \%$ of cases, while the AChA reported here, tropicamide, has only been implicated in two previous instances ${ }^{8,9}$. The case presented here had a clear temporal relationship between symptoms onset and initiation of treatment and a particular aspect in comparison with the two other related with tropicamide already reported: the presence of most of the major risk factors for delirium, psychosis and visual hallucinations in subjects using systemic $A C h A^{1,5}$, including significant cognitive abnormalities, advanced age and visual deficits.

Table 1. Demographic and frequency data of all cases of cycloplegic induced psychosis found in the literature review

\begin{tabular}{llll}
\hline & $\mathbf{n}$ & sex (f:m) & mean age $^{*}$ \\
\hline Atropine $^{\mathrm{a}}$ & 12 & $7: 5$ & $39.9 \pm 28$ \\
Homatropine $^{\mathrm{b}}$ & 5 & $2: 3$ & $42.5 \pm 36$ \\
Ciclopentolate $^{\mathrm{c}}$ & 12 & $4: 8$ & $12.2 \pm 12.4$ \\
Tropicamide $^{\mathrm{d}}$ & 2 & $1: 1$ & 28 \\
Scopolamine $^{\mathrm{e}}$ & 9 & $4: 5$ & $36.3 \pm 26.5$ \\
& 40 & $18: 22$ & $26.6 \pm 25.6$ \\
\hline
\end{tabular}

* years \pm standard deviation; references: a: 2,4 e $7 ;$ b: 2 e 10; c: 2; d: 8 e 9; e: 2 . 


\section{CONCLUSION}

This observation is in line with our own experience of similar complications following the use of sublingual atropine drops for the treatment of sialorrhea in elderly patients with parkinsonism, indicating that these predisposing aspects can be extrapolated to topical agents, assisting in the prevention and early recognition.

\section{COMPETING INTERESTS, FUNDING}

The authors declare no competing interests.

\section{REFERENCES}

1. Cancelli I, Beltrame M, Gigli GL, Valente M. Drugs with anticholinergic properties: cognitive and neuropsychiatric side-effects in elderly patients. Neurol Sci. 2009;30:87-92.
2. Jiménez-Jimenez FJ, Alonso Navarro H, Fernandez Diaz A, Adeva-Bartolomé MT, EzquerroRuiz JJ, Martín-Prieto M. Neurotoxic effects induced by topical administration of cycloplegics a case report and review of the literature. Rev Neurol. 2006;43:603-9.

3. Manny RE, Hussein M, Scheiman M, Kurtz D, Niemann K, Zinzer K. COMET Study Group. Tropicamide (1\%): an effective cycloplegic agent for myopic children. Invest Ophthalmol Vis Sci. 2001;42:1728-35.

4. Varghese S, Vettah N, lyer K, Puliyel JM, Puliyel MM. Ocular atropine induced psychosis: is there a direct access route to the brain? J Assoc Physicians India. 1990;38:444-5.

5. Soeda S, Terao T, Nishimura M, Nakamura J, Iwata N. Aging and visual hallucinations in elderly psychiatric outpatients. Prog Neuropsychopharmacol Biol Psychiatry. 2004;28:401-4.

6. Schadlu AP, Schadlu R, Shepherd JB 3rd. Charles Bonnet syndrome: a review. Curr Opin Ophthalmol. 2009;20:219-22.

7. Mélivier VM. A case of atropine poisoning. Lancet. 1935;2:1232.

8. Hollender MH, Jamieson RC, McKee EA, Roback HB. Anticholinergic delirium in a case of Munchausen syndrome. Am J Psychiatry. 1978;135:1407-9.

9. Jamieson R, McKee E, Roback H. Munchausen's syndrome: an unusual case. Am J Psychother. 1979:33:616-21

10. Tune LE, Bylsma FW, Hilt DC. Anticholinergic delirium caused by topical homatropine ohpthalmologic solution: confirmation by anticholinergic radioreceptor assay in two cases. J Neuropsychiatry Clin Neurosci. 1992;4:195-7. 